\title{
Enhancing Pension Adequacy While Reducing the Fiscal Budget and Creating Essential Capital for Domestic Investments and Growth: Analysing the Risks and Outcomes in the Case of Greece
}

\author{
Georgios Symeonidis * (D), Platon Tinios and Panos Xenos (D) \\ Department of Statistics and Insurance Science, School of Finance and Statistics, University of Piraeus, \\ Karaoli ke Dimitriou 80, 18534 Piraeus, Greece; ptinios@unipi.gr (P.T.); pxenos@unipi.gr (P.X.) \\ * Correspondence: george.simeonidis@gmail.com
}

check for updates

Citation: Symeonidis, Georgios, Platon Tinios, and Panos Xenos. 2021 Enhancing Pension Adequacy While Reducing the Fiscal Budget and Creating Essential Capital for Domestic Investments and Growth: Analysing the Risks and Outcomes in the Case of Greece. Risks 9: 8 https://doi.org/10.3390/risks9010008

Received: 4 November 2020 Accepted: 23 December 2020 Published: 29 December 2020

Publisher's Note: MDPI stays neutral with regard to jurisdictional clai$\mathrm{ms}$ in published maps and institutional affiliations.

Copyright: (C) 2020 by the authors. Licensee MDPI, Basel, Switzerland. This article is an open access article distributed under the terms and conditions of the Creative Commons Attribution (CC BY) license (https:// creativecommons.org/licenses/by/ $4.0 /)$.

\begin{abstract}
Many countries around the world are resorting to mandatory funded components in their multi-pillar pension systems with the purpose of catering for the financial pressure from ageing. This paper aims at analysing the possible replacement rates for such a scheme, by choosing different assumptions and setting the best combined area for the expected result. Then, an approach for analysing the potential for the implementation of such a scheme in Greece is presented along with the actuarially projected expected benefit expenditure and respective accrued capital. A result of the introduction of such a component is expected to be the elevated replacement rate at retirement with a concurrent alleviation of the fiscal burden for the state. The projected scale of savings will also provide domestic financing for investments generating growth.
\end{abstract}

Keywords: funded pensions; adequacy; capital investment; growth

\section{Introduction}

This paper aims to estimate the effect on replacement of the potential introduction of a mandatory fully funded scheme in the Greek pension system. This goal will be achieved by analysing three parameters and providing an approach to determining the optimal mix of the three. The proposed approach is based on a three-dimensional analytical tool that brings together the essential parameters: (1) The average number of years of the annuity (e.g., life 2 expectancy at the age of claiming the annuity), (2) the expected return on investments, and (3) the contribution rate applied to the pensionable earnings of the nation's participants. An actuarial projection of the benefits and contributions (assets) using the cohort method for the total of employed people in Greece is also conducted to provide an analysis of the projected effects of a possible implementation of this system on the accrued capital, the government budget and over national debt.

The Greek pension system is likely to suffer a great deal in the future due to the population ageing, with a 16\% decline in population from 2019 to 2060, while at the same time, it has been underfunded in the past decades (EPC 2015b, 2015c, 2018). The state is also expected to be one of the four European states to surpass $65 \%$ old-age dependency ratio in 2070 (EPC 2020). Moreover, since Greece's population is dramatically shrinking, this is expected to put great pressure on the country, with a quickly rising demographic dependency ratio, compared to the European average (EPC 2018). The sustainability of the system has long been in question. Recent pension reforms have proved unsuccessful in restoring the financial stability of the pension system (EPC 2015b, Symeonidis 2016). The pension expenditure in Greece has exceeded 17.5\%, of Gross domestic product (GDP) in 2016 (Eurostat 2019) with the European average at 11.2\% of GDP, while contribution rates vary from 27 to over $30 \%$ for the pension branch, being one of the highest rates in the EU (EPC 2018). Such a burden to the economy nurtures uncertainty for pensioners and 
undermines competitiveness. Except for the continuous legislation changes, horizontal pension cuts have deprived some pensioners of more than $50 \%$ of their income. Losses were heaviest among those contributing most, which is inversely proportional to reciprocity ${ }^{1}$. The reforms and cuts were all a result of the necessity of external funding of the Greek economy by the European Commission, the European Central Bank and the International Monetary Fund after the Greek prime minister turned to these for help in 2010, under extreme financial conditions and near bankruptcy. In 2017 and 2018 there seems to be a slight increase in contribution collection brought by the latest legislation, but nevertheless the funding gap of the system remains close to $50 \%$ (Government Official Journal 2018). In this respect, providing financial stability while securing adequate pensions and acceptable level of consumption in retirement incomes remains a very difficult task to achieve, especially when (Pay-As-You-Go) PAYG systems are coupled with intense population ageing.

PAYG has the dominant role in the Greek pension system, while occupational schemes and private insurance are practically non-existent. More explicitly, PAYG (social security benefits) payments for primary and secondary pensions in 2017 and 2018 amounts to 24 billion EUR per year (Government Official Journal 2018), while occupational pension funds pay almost 90 million EUR (OECD.stat 2020) and private insurance companies almost 28 million EUR (Hellenic Association of Insurance Companies 2020).

Looking into the developed countries as a whole, foreseen intense population ageing poses a financial burden in public pension systems in the present or near future. (European Commission 2010, 2012; OECD 2015, 2017). Most European countries that have mature payas-you-go (PAYG) defined benefit schemes are facing problems in financing these programs due to program maturation, population ageing, prior promises of overly generous benefits, changes in employment patterns or a combination of the above. The most common practice for these countries were parametric reforms or systemic reforms, which helped public pension systems deal with the increased financing needs (EPC 2015c, 2018).

The rest of the paper is arranged in five sections as follows. The second section provides a brief literature review on the introduction of funded schemes internationally and the relativity of the latter to the promotion of savings and potential growth. In the following section, we present the methodology and all necessary equations together with the corresponding parameters are discussed. We then present and explain the results in the fourth section. In the final section, we make discussion on and the aforementioned results. Further analysis is provided in the same section addressing the use of these findings in the implementation of funded schemes, and the Greek case is specifically stressed.

\section{Literature Review}

Some countries decided to introduce mandatory fully funded pension schemes, as a second tier to the PAYG tier. Recent developments have led law-makers to acknowledge that fully funded components can be an integral part of an adequate third-age income. In this direction, several countries, including Sweden and some Eastern Member States such as Bulgaria, Estonia, Croatia, Latvia, Lithuania, Hungary, Poland, and Slovakia, have switched part of their public pension schemes into (quasi-) mandatory private funded schemes (EPC 2018). The introduction of funded pillars gained momentum across Europe after the 1990's (Feldstein 1995, 1996, 1998). However, the reversals which followed the 2008 economic and financial crisis actually reduced or completely eliminated the role of funding in many countries (Bielawska et al. 2017).

One of the main arguments in favour of funded schemes is that they promote growth. Davis and $\mathrm{Hu}$ (2008) argue that funding of pensions connects to higher economic growth, especially for emerging market economies, due to higher saving rates, capital market development and reduced labor market distortions. The OECD (2013) likewise stresses the importance of private pensions to economic growth, looking into the institutional role

1 Horizontal pensions cuts refer to the reduction in pension amounts based on the sole criterion of the amount itself. For example, a $20 \%$ reduction of all pensions above 1200 euros. 
of private funds, while the latter continue to grow and invest. (Bijlsma et al. 2014) link growing pension savings to general economic growth, through the investment of fund assets. Zandberg and Spierdijk (2013) conclude that the long-run effect on growth borne out of funded pensions is positive when using estimates from a model with overlapping observations, but the effect is not the same when a simple cross-sectional model is used. However, both Davis and Hu as well as Zandberg and Spierdijk (2013) have been challenged by (Cavallini et al. 2013). The latter proceeded to re-estimate the Davis and Hu (2008) by using the total pension fund assets definition of Zandberg and Spierdijk (2013) and a more sophisticated common correlated effects mean group (CCEMG) and common correlated effects pooled (CCEP) estimators (accounting for a multifactor error structure) for $12 \mathrm{OECD}$ countries over the period 2001-2010. (Cavallini et al. 2013) have ultimately found no evidence of a long-term relationship between pension fund assets and economic growth.

Overall, the preliminary data for 2019 show that pension funds held USD 32.3 trillion in the OECD area (OECD 2020) while the nominal investment rates of return of all funded and private pension plans vary between $2.3 \%$ and $9.7 \%$ for the years $2015-2019$ (OECD 2019a).

Having said that, let there be no doubt that funded schemes, as PAYG schemes, also come with flaws. After all, the main question that Lindbeck and Persson (2003) asked before reforming the Swedish pension system, whether there is an ideal system, remains rhetorical in essence. On the one hand, according to Barr (2000) it would be possible to achieve essentially the same result by making similar benefit cuts and tax increases in the existing PAYGO DB schemes, but this has not proved to be very successful, maybe because of the political implications it involves, rather than introducing a new pension type. On the other hand, in the funded schemes, fluctuations in stock and bond markets are the principal risk experienced by investors; this is why a funded component must always be part of a cohesive savings strategy including the other, ostensibly safer, pillars and components. More specifically, Góra and Palmer (2020) conclude that, although funded schemes are expected to generate a higher rate of return than notional funded schemes, they are considerably more volatile, which makes them appropriate for a second pillar but not a first universal (mandatory) public pillar. As regards the differences in efficiency between fully funded and notional schemes, Góra and Palmer (2004) further compare the efficiency of the fully funded schemes as opposed to other types of schemes concluding amongst other that the fully funded schemes are potentially superior to notional schemes because they can create saving and promote financial market development. Finally, Holzmann and Hinz (2005) argue that successful reform of pensions depends first and foremost on a careful consideration of the macroeconomic and fiscal environment and whether the latter can support the reform.

\section{Methodology}

\subsection{Funded Schemes-Formulas and Parameters}

Let us analyse the three parameters mentioned above (annuity, return on investment, contribution rate) and build on the logic of our calculations. The idea behind funded systems is that each contributor sets aside a certain amount of money per period of time; in the end of their working life, they get back the accumulated funds. These correspond to the future present value of the amounts paid, increased by the return on investment, and paid out in the form of a lifelong pension flow (annuity).

Hence, a simplified formula describing the accrued amount would be:

$$
\text { Acc }=\sum_{i=1}^{n} X(1+i)^{n}
$$

where:

Acc: is the accrued amount at retirement,

$X:$ is the amount of contributions per year (assumed fixed),

$i$ : is the yearly rate of return on investment, 
$n:$ is the number of years of contribution

\subsubsection{The Baseline Scenario Analysis}

Let us assume that a new mandatory, fully funded system starts today, without any financial burden from past commitments. The potential transition from an already existing system and its financial burden is not analyzed in this paper and could be a topic for further analysis. A critical indicator in such a system is the projected replacement rate at the time of retirement. The replacement rate is defined as the fraction of the first pension amount, over the last wage. Sometimes, yet not in this paper, the denominator is also computed as the average career income instead of the last wage, which introduces an element of confusion. In order to calculate representative replacement rates for the fully funded system, we first have to further specify formula (1).

Starting from formula (1) and looking into a more complex case, we can account for income variability and maturity, in order to calculate the required contribution rate as a percentage of a specific amount of income (e.g., $6 \%$ on earnings). In addition, we can take into account a percentage of expenses on contributions. In this context, the accrued amount at time $n$ shall be given by:

$$
A c c_{n}=X_{n} *(1-E)(1+i)^{\frac{1}{2}}+A c c_{n-1}(1+i)
$$

where:

$A c c_{n}$ : is the accrued amount at time $n$,

$X_{n}$ : is the amount of contributions at time $\mathrm{n}$ as percentage of income, before expenses,

$E$ : is the percentage of expenses on contributions,

$i$ : is the yearly rate of return on investment,

$n$ : is the number of years of contributions

The annual return rate on investment (i) is assumed to be constant for the purpose of simplicity. Payments are assumed monthly; hence, the amount of the last year is multiplied by $(1+i)^{\frac{1}{2}}$ as if there were one payment in the middle of the year, to simplify.

Let us use formula (2) and proceed to calculate the replacement rate for a proposed funded scheme. To do that, certain additional assumptions are needed. These are the salary maturity per year ${ }^{2}$, a possible contribution rate which would serve as a norm or as the minimum $^{3}$, an expense rate on contributions and a real return rate (after expenses).

An annuity is needed to convert the funds accumulated into a pension at retirement. In most of the developed countries but also elsewhere, recent legislation and reform trends indicate a full working career of about 40 years for a full pension and the retirement age thresholds are typically at an age between 62 and 67 years. In this paper, the full career is assumed to be close to the maximum, hence 40 years. We shall also assume an average/representative annuity of 15.64 , which is a joint annuity based on EVK $2000^{4}$ and HAS $^{5} 2005$ tables. This annuity corresponds to the Greek mandated (67) age threshold which is slightly higher than the effective retirement age in most cases. However, given extensive reforms over the bailout period, forward-looking assumptions may reasonably differ from historical data. Since, however, the mortality tables come in many variations according to country, e.g., continent, race, employment, and so on, so other values for the annuity are also assumed in the sensitivity analysis.

2 The percentage of increase of a person's salary due to legislated increase based on more years of work, an increase in pay or a promotion.

3 Legislators are expected to present people with a standard percentage of contribution to either begin with or serve as the standard where choice is not made.

4 EVK2000 is the official mortality table for valuations reported to the Secretariat-General for Social Insurance, based on Gazette B1432/2006, Ministerial Decision 2. Mortality of Greeks is greater than that of the Swiss, a fact which provides better benefits when the EVK2000 is used for the Greek population.

5 Hellenic Actuarial Society. 
Since we are looking into a scheme that is mandatory, a minimum contribution rate on pensionable earnings is assumed for organizational reasons. This will be set at $6 \%$ of pensionable earnings to begin with, based on European experience (European Commission 2008). Further analysis on other possible contribution rates is provided in the sensitivity scenarios. Other assumptions include $0.5 \%$ maturity per year on income and an expense rate of $0.5 \%$ on contributions.

The real return rate (RRR) is our final and maybe the most important variable and should be thoroughly investigated before selecting a working assumption for our baseline. Firstly, there is a case to be made about current returns being very low because of quantitative easing ${ }^{6}$ in an attempt to reduce the effects of the recent monetary crisis that started in 2008 (Rajan 2019) and more recently with the depression that started in February 2020 due to the COVID-19 pandemic. In his comparative report, covering almost 200 pension funds, with more than 3 trillion assets under management/advisement, in $50 \%$ of pension plan respondents, quantitative easing was reported to have undermined the longer-term financial viability of pension plans. At the same time, $62 \%$ of respondents reported that quantitative easing has overinflated the value of pension liabilities via zero-bound interest rates. It is also mentioned that falling rates also inflate the present value of future liabilities, as measured under prevailing pension regulation. As a ball park estimate, the report mentions, a $1 \%$ fall in rates delivers a $20 \%$ rise in pension liabilities and a $10 \%$ fall in the funding ratio-a measure of a plan's ability to meet its future commitments. As with very low or zero interest rates, negative interest rate policy also creates problems as regards pension returns as these exacerbate effects of low (but positive) policy rates and quantitative easing (IMF 2017).

Expanding the view to a longer period, as regards future returns, Gratton and Scott (2018) argue that it is important to use longer historical data periods for forecasts, as many as 100 years or even more. Based on data from Credit Suisse, they calculated return rates for many large countries for the years 1900 to 2014 and concluded that the long-term returns for zero-risk investments was close to $2 \%$ for the US, but $6.4 \%$ for risk premiums. Consequently, for a mixed portfolio of $50 \%$ zero risk bonds and $50 \%$ stocks, one would earn $4.2 \%$ on average in the long term. For the UK, the respective return is $3.5 \%$. The average historical returns for the US, the UK, Japan, Germany, France, and Australia are $2.8 \%$ above inflation. In the $\operatorname{OECD}(2015,2017,2019 \mathrm{~b})$, the real rate of return on funded, defined contribution pensions for calculations is assumed to be $3 \%$ per year.

In the Pension Adequacy Report (European Commission 2018), the assumed rate for the base case is $3 \%$ while the interest rate assumed to calculate the annuity is $0.8 \%$ lower than the assumed rate used during the accumulation phase, in order to account for the cost of buying the annuity, administrative and management expenses.

Based on the analysis of the averages of the 20-year through 30-year maturity of the Zero-coupon yield curve spot rates of AAA-rated euro area central government bonds and the whole euro area central governments bonds (Eurostat 2018), we see in the table below that the averages vary between $2.12 \%$ to $2.76 \%$. This gives values, which have to be assumed as minima, as the whole period of the crisis is included. Table 1 contains zero-coupon yield curve spot rates for all Euro Area (EA) bonds as well as all AAA bonds, for different time intervals and years of maturity.

6 Quantitative easing (QE) is a form of unconventional monetary policy in which a central bank purchases longer-term securities from the open market in order to increase the money supply and encourage lending and investment. Buying these securities adds new money to the economy, and also serves to lower interest rates by bidding up fixed-income securities. It also expands the central bank's balance sheet. Source: https: //www.investopedia.com/. 
Table 1. Zero-coupon yield curve spot rates.

\begin{tabular}{ccccc}
\hline Maturity/Time & $\begin{array}{c}\text { All EA Average } \\
\mathbf{1 0}(\mathbf{2 0 0 8 - 2 0 1 7 )}\end{array}$ & $\begin{array}{c}\text { AAA Average } \\
\mathbf{1 0}(\mathbf{2 0 0 8 - 2 0 1 7 )}\end{array}$ & $\begin{array}{c}\text { All EA Average } \\
\mathbf{1 0} \text { (2004-2013) }\end{array}$ & $\begin{array}{c}\text { AAA Average } \\
\mathbf{1 0} \text { (2004-2013) }\end{array}$ \\
\hline Maturity: 10 years & 2.82 & 2.12 & 3.86 & 3.38 \\
Maturity: 20 years & 3.50 & 2.73 & 4.38 & 3.88 \\
Maturity: 25 years & 3.61 & 2.77 & 4.46 & 3.91 \\
Maturity: 30 years & 3.65 & 2.76 & 4.48 & 3.90 \\
\hline
\end{tabular}

Source: (Eurostat 2018), calculations by authors.

If we look back at earlier years, the respective values are much higher, reaching $5 \%$ for the years 2004-2013. If we looked back at the data even before the crisis started, the rates would rise even more. For example, the respective spot rate for 20-year maturity of EA bonds was 5.5\% in 1999 (Eurostat 2012). The deep correction during the Greek crisis could imply, as happened in the cases of Spain, Cyprus and Portugal, some re-alignment concerning returns especially in the first post crisis years. In conclusion, the baseline case, a $3.5 \%$ return is a prudent assumption for a time period close to the full working career. The authors do take into account that there is intense discussion (Lukaszl and Summers 2019; Schmelzing 2020) about the long-term decline on returns and treat this issue with sensitivity analysis in Section 3.1.2.2, where a minimum return of $2 \%$ is chosen.

Blending the two aforementioned inquiries, we choose RRR in our basic scenario to be $3.5 \%$. Using the assumptions mentioned before and outlined in Table 2, we estimate that the replacement rate is calculated at $26.02 \%$ for 40 years or $0.65 \%$ yearly, for an annuity of 15.64 years. These can be found in Table 2.

Table 2. Assumptions on calculating the replacement rates for the defined contribution fund ETEA.

\begin{tabular}{cc}
\hline Income maturity & $0.50 \%$ \\
Total contribution rate & $6.00 \%$ \\
Expenses on contributions & $0.50 \%$ \\
Total working life in years & 40 \\
Expected life of the annuity & 15.64 \\
\hline
\end{tabular}

Source: calculations by authors.

We observe that the replacement rate covers a significant amount of return on retirement, with a contribution of $6 \%$ on pensionable income. To benchmark this for the Greek case (follows in the paradigm section), let us say that for the same amount of contributions, the present system replaces at $0.45 \%$ yearly. More specifically, the latest pension reform of 2016 replaces contributions at $0.45 \%$ yearly for the years until 2014, while for 2015 and on the system works on NDC principles and takes into account the annual wage growth. Let us look at the further options for replacement below, while expanding the main calculation variables chosen in the baseline.

\subsubsection{Sensitivity Analysis}

In the previous subsection, a careful selection of assumptions was made. However, sensitivity analysis is deemed necessary so that possible extreme behaviour of the system is highlighted while still in the planning period.

\subsubsection{Annuity Sensitivity}

One of the assumptions to analyse further would be the annuity and the expected life span it refers to. Life expectancy not only varies greatly from country to country, but is also increasing. Moreover, the choice of whether or not to transfer the annuity to a spouse, if the contributor dies, implied a range of values to look into in order to determine the possible outcomes for the respective replacement rates.

The normal retirement age for men and women around Europe varies between 62 and 67 years old, while some countries (EPC 2018) tend to reform in the direction of a 
part of the future increase in life expectancy be incorporated in the statutory retirement age. The fully funded private pension schemes are not usually subject to a minimum retirement age, as the choice of leaving the work force is based on the amount amassed at that point, since ownership is one of the most important aspects of such funds. However, since this paper is looking into a mandatory funded scheme, which in the Greek case will go hand-in-hand with the social security pension, it is prudent that people be asked to fulfil the criteria for a primary pension before retiring from the funded scheme. Having chosen an annuity based on the EVK2000, we now enrich our research using the mortality tables GR1990 ${ }^{7}$, PM6064 ${ }^{8}$, and HAS 2005 and 2012 tables. Based on these, we will look for a possible annuity range to fulfil the sensitivity analysis, focusing on the most recent tables. For the PM6064 mortality table, we calculate ages at last birthday, (e.g., age 67.7 is calculated as age 67) and subtract five years for women and two years for men in order to better convey the increase in longevity and allow for the fact that these tables are dated. This method-using PM6064 and subtracting years to cater for the increase in longevity - is common/standard practice in the Greek pension calculations ${ }^{9}$. The results are depicted in the tables below. Table 3 refers to the average length of the pay-out period with longevity based on unisex life expectancy for women as well as men for the first two columns, and to each gender for the next four.

Table 3. Ages and respective annuities under different mortality tables.

\begin{tabular}{ccccccc}
\hline & EAA2012 & EAA2005 & \multicolumn{2}{c}{ PM6064 } & \multicolumn{2}{c}{ GR1990 } \\
\hline AGE & Unisex & Unisex & Men (-2) & Women (-5) & Men & Women \\
\hline 62 & 24.70 & 21.71 & 16.30 & 18.39 & 18.36 & 21.04 \\
63 & 23.84 & 20.90 & 15.63 & 17.68 & 17.62 & 20.18 \\
64 & 22.99 & 20.11 & 14.97 & 16.98 & 16.88 & 19.32 \\
65 & 22.15 & 19.34 & 14.33 & 16.30 & 16.16 & 18.47 \\
66 & 21.32 & 18.57 & 13.71 & 15.63 & 15.46 & 17.62 \\
67 & 20.50 & 17.82 & 13.10 & 14.97 & 14.77 & 16.80 \\
68 & 19.70 & 17.08 & 12.50 & 14.33 & 14.10 & 15.98 \\
69 & 18.91 & 16.36 & 11.93 & 13.71 & 13.45 & 15.19 \\
70 & 18.13 & 15.66 & 11.37 & 13.10 & 12.81 & 14.42 \\
\hline
\end{tabular}

Source: Calculations by authors.

As long as the legislated normal retirement age for the primary pension in Greece is still 67 , a prudent set of values derived from the above table is from 14.00 and proceeding to value 18.00 , with a 0.1 interval. The replacement rates arising from the main annuity values can be found in Table 4 .

Table 4. Main annuity values and respective replacement rates.

\begin{tabular}{cccccc}
\hline Annuity & $\mathbf{1 4}$ & $\mathbf{1 5}$ & $\mathbf{1 6}$ & $\mathbf{1 7}$ & $\mathbf{1 8}$ \\
\hline Replacement & $29.10 \%$ & $27.10 \%$ & $25.40 \%$ & $24.10 \%$ & $22.70 \%$ \\
\hline
\end{tabular}

Source: calculations by authors.

\subsubsection{Return Rate Sensitivity}

As mentioned earlier, sensitivity analysis on rate of return values is very important. Looking back at Table 1, we may assume values for the return rate varying between $2 \%$ and $6 \%$. This spectrum of values covers possible cases of prudent assumptions between lower returns for crises and higher returns during intense financial growth. Again, a step

\footnotetext{
7 Greek Mortality Tables, 1990 data.

French Mortality Tables, Assured Lives, 1960-1964 Experiences, Male, used in the Greek Actuarial calculations in the past.

9 Ministerial Decree D K4-4381/1979.
} 
of $0.1 \%$ has been chosen. The main values of the return rate and respective replacement are depicted in Table 5 below:

Table 5. Main return rate values and respective replacement rates.

\begin{tabular}{cccccc}
\hline Return rate & $2 \%$ & $3 \%$ & $4 \%$ & $5 \%$ & $6 \%$ \\
Replacement & $18.80 \%$ & $22.80 \%$ & $28.50 \%$ & $36.80 \%$ & $46.90 \%$ \\
\hline Source: calculations by authors.
\end{tabular}

\subsubsection{Contribution Rate Sensitivity}

The initial/minimum contribution rate as proposed for this funded scheme is $6 \%$ on pensionable earnings. Since, however, this scheme is assumed to be fully funded, it is logical that higher contribution rates can be accepted so that people willing to set more money aside for their old age earn a higher replacement. European Commission (2008) presents the contribution rates to privately managed funded schemes across different European countries and these vary between $5 \%$ and $9 \%$. Therefore, starting from the proposed minimum to be legislated, we examine the replacement rates for a step of $0.1 \%$ up to $10 \%$. Table 6 shows the main contribution rate values and respective replacement rates.

Table 6. Main contribution rate values and respective replacement rates.

\begin{tabular}{|c|c|c|c|c|c|}
\hline Contribution rate & $6 \%$ & $7 \%$ & $8 \%$ & $9 \%$ & $10 \%$ \\
\hline Replacement & $26.00 \%$ & $30.40 \%$ & $34.70 \%$ & $39.00 \%$ & $43.40 \%$ \\
\hline
\end{tabular}

\subsection{Methodology for the Greek Case Study}

The Greek case study has been utilized using the cohort simulation projection method. Several European countries use such models for their social security systems (European Commission 2007) Cohort simulation projection models are based on up-to-date crosssectional information regarding the labour activity and social security contributions by various social groups (cohorts). Further break-down by gender, position in the labour market and demographic characteristics is also possible and has been taken into consideration (TARKI 2008). The input is based on aggregate data for the cohorts instead of person-by-person specific data. The averages are projected for each year using formulas for demographics and finances. The transition from year $t$ to year $t+1$ changes the status of a person (active, inactive or pensioner) and is mapped onto the following year using the actuarially assumed transition probabilities. These are included in the mortality tables as analysed earlier in the text, and the assumptions on retirement rates which are calculated through the experience of the historical data of the last few years before the base year of the projection.

The projection of the active population from $t-1$ to time $t$ is expressed by the following equation:

$$
\operatorname{Act}(x, s, t)=\operatorname{Act}(x-1, s-1, t-1) \cdot p_{x-1}(a a)
$$

The interpretation of the above equation is the following:

The active population at time $t$, aged $x$ with s years of past service equals the active population aged $x-1$ of the previous year, with $s-1$ years of service multiplied by the probability of a person aged $x-1$ to stay active. An active person may become inactive through retirement, invalidity, death and unemployment.

On the income side, the contribution base can be calculated as the product of the number of contributors by the average insurable earnings. On the other hand, benefit expenditure is calculated as the result of the product of benefit expenditure in year $(t-1)$ 
by the survival rate of pensioners reaching time $t$, plus the benefit expenditure from newly awarded pensions.

Contribution base $=($ number of contributors $) \times($ average insurable earnings $)$

Benefit Expenditure $=($ benefit expenditure in $(t-1)) \times($ survival rate $)+($ newly awarded pensions $)$

The remainder between contributions collected and benefits paid is capitalized at the end of the projection year, adding to the existing capital from previous years, towards creating the total capital available for investment as presented in the results chapter.

More specifically, benefits are calculated using the average salaries of the projected population for the respective years of service in the projection period and applying the probabilities of exit accordingly. Further, more detailed functions are utilized, as described by Iyer (1999) and Plamondon et al. (2002) per the use of actuarial cohort modelling for social security.

\subsubsection{Assumptions Used in the Projections}

The population projections used in the valuation come from Eurostat. These projections are prepared for each member state and make use of certain assumptions provided by each member state. Greece is expected to receive some of the greatest pressure from the demographic dependency amongst its European counterparts (Figure 1).

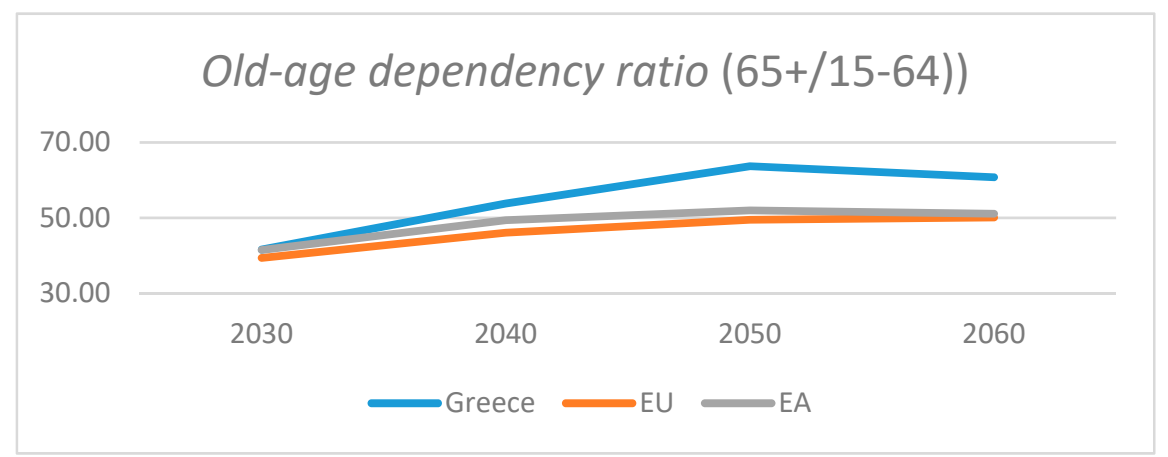

Figure 1. Old-age dependency for Greece, the EU and the Euro Area, years 2030-2060. (Source: (EPC 2015a)).

The set of macroeconomic assumptions used in the valuation was the same used by DG ECFIN (Directorate General for Economic and Financial Affairs of the EU), in the context of the OMC for pensions. The starting point is the EUROPOP2013 population projection for the period 2013 to 2060 (Eurostat 2015). These combined set of projections enabled the calculation of GDP for all Member States up to 2060. It is worth mentioning at this point that the Greek GDP has shrunk by approximately 20\% from 2010 to 2013 and more than 30\% from 2008 to 2013 (Symeonidis and Venetsanakou 2016). The basic macroeconomic assumptions for Greece for the projection period 2013-2016 may be found in (EPC 2015a).

\subsubsection{Labour Force Participation Projections}

In Greece, labour force participation is projected to increase for age group 55-64, from $42.4 \%$ in 2013 to $78.0 \%$ in 2060 . The largest increase will be experienced until 2020, reaching $59.4 \%$. The participation rate for age group 65-74 increases from 4.4 in 2013 to 24.4 in 2060 and this is the main driver behind the results of the projection, reflecting on the changes in social values and the life expectancy (Table 7). 
Table 7. Participation rate, employment rate and share of workers for the age groups 55-64 and 65-74.

\begin{tabular}{ccccccc}
\hline & $\mathbf{2 0 1 3}$ & $\mathbf{2 0 2 0}$ & $\mathbf{2 0 3 0}$ & $\mathbf{2 0 4 0}$ & $\mathbf{2 0 5 0}$ & $\mathbf{2 0 6 0}$ \\
\hline Labor force participation rate 55-64 & 42.4 & 59.4 & 69.4 & 74.5 & 77.2 & 78 \\
Employment rate for workers aged 55-64 & 35.5 & 51.5 & 63.6 & 71.3 & 73.8 & 74.6 \\
Median age of the labor force & 39 & 42 & 44 & 44 & 43 & 43 \\
\hline
\end{tabular}

Source: (EPC 2015a).

The average effective entry age in the labour force is constant for the projection period (22.6 years for men and 24.1 for women). Due to pension reforms the average contributory period is projected to reach 37.8 years for men and 37.5 for women by 2060. The percentage of adult life spent at retirement decreases for both men and women. AWG/EUROPOP2013 assumptions on lab or force participation rates and employment rates have been taken into account.

\subsubsection{Wages, Inflation, Pension Indexation}

The wage growth is obtained by the product of inflation and labour productivity. No negative growth is applied. Salary valorisation is adjusted using the rate of inflation and rate of growth in labour productivity.

This adjustment is higher than the actual increase in the salaries observed in past years, leading to a high valuation of accrued rights and thus pension expenditures observed in the most recent years. On the other hand, it recognizes the high potential for investments in technical progress, including processes that are inherent in a positive economic future for Greece. The inflation rate used in the valuation (GDP deflator) can be seen in Table 10 below. Primary pensions benefit indexation is fully linked to a uniform adjustment index, which cannot exceed CPI. In particular, the index is equal to the minimum of CPI and the sum of $50 \%$ CPI and $50 \%$ GDP growth [min (50\% GDP growth $+50 \%$ CPI, CPI)]. No nominal increase in pensions up to 2015 occurs in the calculations based on current legislation. The formula for secondary pensions benefit indexation according to legal provision is

$$
\gamma_{\mathrm{t}}=\min \left(\left\{1+\mathrm{g}_{\mathrm{t}-2}-\mathrm{r}\right\} * \mathrm{SF}_{\mathrm{t}}-1 \text {, } \text { inflation }_{\mathrm{t}-1}\right)
$$

where g: notional rate of return, $\mathrm{r}$ : discount rate $=1.3 \%$, SF: sustainability factor $=$ Contributions previous year/Benefits previous year. In the case of the DC fund (new supplementary fund) we assume $\mathrm{SF}=1$, hence the $\mathrm{SF}$ does not actually apply. This indexation can take negative values. Table 8 below includes the values for inflation.

Table 8. Inflation values.

\begin{tabular}{lcccccc}
\hline & $\mathbf{2 0 1 3}$ & $\mathbf{2 0 1 4}$ & $\mathbf{2 0 1 5}$ & $\mathbf{2 0 1 6}$ & $\mathbf{2 0 1 7}$ & $\mathbf{2 0 1 8 - 2 0 6 0}$ \\
\hline inflation & -2.1 & -0.7 & 0.4 & 1 & 1.5 & 2 \\
\hline Source: (EPC 2015b). & & &
\end{tabular}

In the valuation, the participation rates for employment are assumed to be 2 percentage points higher per year, for the age group 20-64 compared to the baseline. The increase is linear in the period 2016-2025 and remains stable thereafter. Experience has shown (OECD 2011, Carone and Salomäki 2001 and Van Rijckeghem 1997) that the reduction of contributions has helped boost employment, so this scenario is the most appropriate in our case. This scenario is the main scenario used throughout the pension projections.

This valuation covers all available labour force and works under the main principle that all people working will in fact be contributing to some supplementary fund. To this day, this is not the case, as some portions of the population, like doctors and engineers, do not contribute to such funds. The main contributors for the secondary pension in 
Greece are private employees and civil servants. Most of the current contributors for the supplementary pension are enrolled in one large fund named ETEAEP ${ }^{10}$.

The coverage statistics can be found in Table 9 below.

Table 9. Total insured population.

\begin{tabular}{cc}
\hline Base Year (2013) Coverage Percentages & Insured \\
\hline SQ total & $4,188,200$ \\
Labor Supply = DC Contributors & $4,188,200$ \\
& $100 \%$ \\
\hline
\end{tabular}

Source: Calculations by authors, (EPC 2015b).

While the individual replacement rates for this paper are calculated solely on the respective annuities and other chosen assumptions, the use of a cohort model is implemented so the total insured population is projected accordingly, and all the available decrements are taken into account. For this reason, the outputs of the Hellenic Actuarial Authority valuation year 2015 are also used and adjusted as such. The data used are in two main categories, individual data and consolidated data.

The minimum retirement age for full pension as legislated in 2010 and modified in 2012 has reached 67 years of age with the alternative of 62 , if 40 full years of contributions have been fulfilled. Furthermore, the minimum retirement age been linked to life expectancy change at year 65 . Therefore, a further increase in retirement age minimum has been modelled for years 2021, 2030, 2042, and 2051 by one year.

As stated earlier, the projection assumes that the total supply of the employed people contributes to the new capitalized fund. For this reason, the results of the 2015 valuation (EPC 2015b) are up scaled so that the population includes the full supply of employed people. This means that more active population is assumed so as the labour supply number provided actually matches the real number of people recorded in the market. Table 10 presents the number of contributors for the capitalized fund of the supplementary pension.

Table 10. Funded scheme Contributors (total employed persons).

\begin{tabular}{cc}
\hline Year & Number of Employed \\
\hline 2020 & $4,665,652$ \\
2030 & $4,993,526$ \\
2040 & $4,922,508$ \\
2050 & $4,467,694$ \\
2060 & $4,189,135$ \\
\hline
\end{tabular}

Source: Calculations by authors.

A calculation of the total contribution revenue flowing into the system is necessary, so as to present the volume of investment funds available and their possible impact on GDP growth. The population and contribution margin have been adapted so they include the total working population, and the contribution percentage is $6 \%$. The macroeconomic scenario used is-as stated earlier-the higher employment scenario and this means that new entrants are calculated with the increased employment rate.

\section{Results}

\subsection{Results for the Funded Scheme's Replacement}

Summing up the baseline scenario and the three sensitivity criteria results, the next step is to define an interval within which a measurable replacement rate is born. Drafting all the necessary data in Matlab (R2019b) we create Figure 2 below, a color-coded threedimensional graph. The contribution rate lies on the left axis, measuring from $6 \%$ to $10 \%$ on 
pensionable earnings. The annuity, plotted for values $14-18$, lies on the bottom left axis, and the return rate on the bottom right, for values $2 \%$ to $6 \%$. The replacement is color-coded and the code legend lies on top, dark blue being close to $0 \%$ and graduating to red, which reaches to as much as $100 \%$, as it gets darker in colour. The warmer the colours, the higher the corresponding replacement rate. The colder the colours, the lower the replacement rate, respectively. An area of special interest to us is that of the replacement rates close to $30 \%$. For this area, color-coded white, we can see possible combinations that would derive the necessary replacement. This area proves an important point towards the attainment of such a replacement rate. All three parameters can be useful in this direction, and even returns as low as 3.5\% can provide a decent replacement, provided the annuity and contribution rate are such that they allow this. All three parameters are important in order to achieve the goal of a decent return on contributions, but can be off-set by the remaining two parameters if someone has not been putting aside a substantial percentage of their income, decide to leave earlier or the market does not reach its full potential respectively.

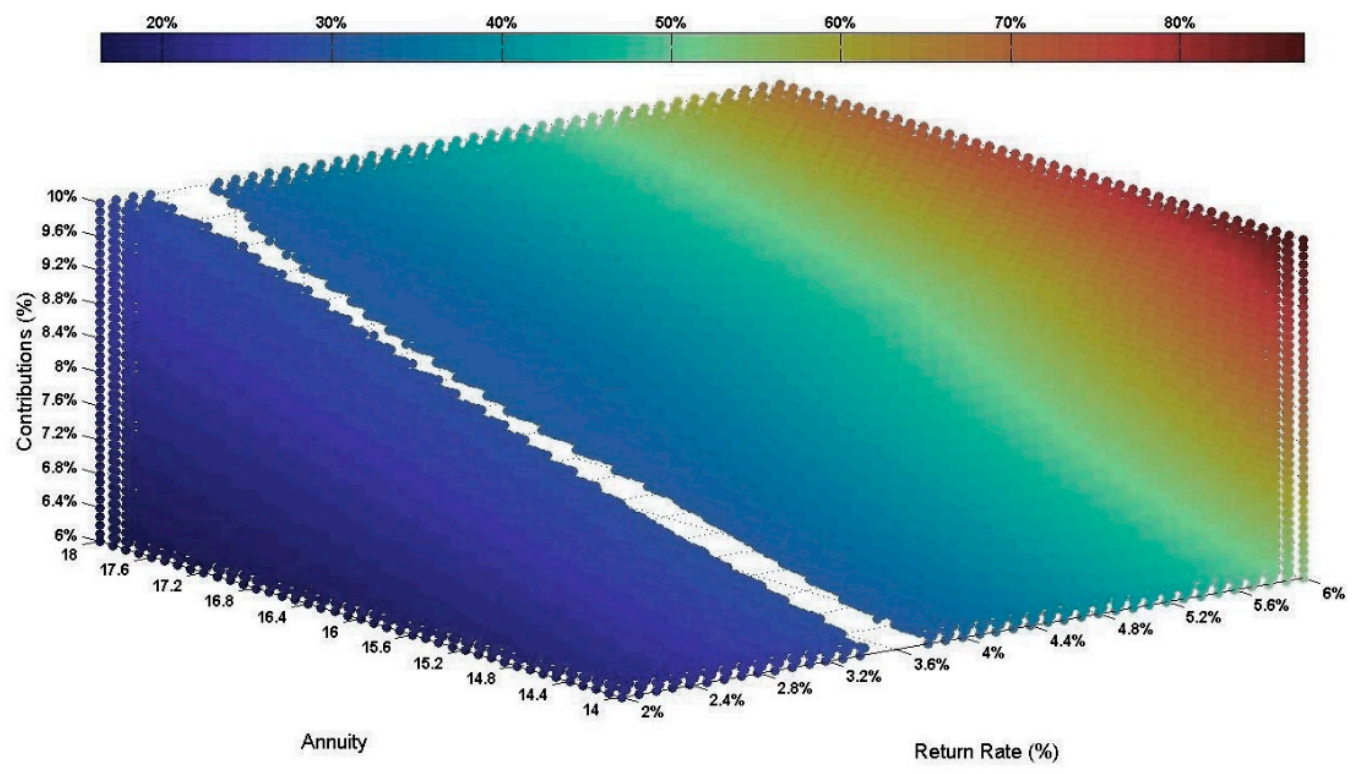

Figure 2. Combined sensitivity analysis of the contribution rate, annuity and the rate of return and the different respective replacement rates. (Source: Calculations by authors).

For other total replacement rate values, one has to look at the coloured line on top, which explains the colour codes and then refer to the diagram below matching the respective colour zone.

An example to help understand this graph would be to choose a value from the far-right part of the white line, e.g., 3.6\% for RRR, which intersects to annuity life value 14.4. On the far left, this corresponds to almost $6.2 \%$ contribution rate. In this case, the replacement rate for these parameters amounts close to a $30 \%$ target.

In general, the far right and far left sides represent the two diametrically opposed areas, providing very high and very low return rates respectively. The graph can be used to obtain different results when combining the three parameters in questions, then the colour that corresponds to the combination can be matched to the legend on the top of the graph.

\subsection{Results for the Greek Case Study}

A new pension funded scheme comes with great policy challenges before its implementation. To begin with, extensive changes should be applied to the legal framework already in place in order to account for the new funded scheme. Most researchers would place this scheme under a second pillar, however Paparigopoulos (2019) states that funding of pensions does not necessarily mean the new scheme cannot be installed in the first 
pillar, from a legal perspective. A further analysis of some policy aspects can be found in (MoL 2019). One of the most sensitive matters discussed is the introduction of investment rules that apply to the fund manager(s) and that they must be described in legal detail. While a functioning capital market must be in place for investments to work properly, if the state decides to install the funded scheme in the first pillar, any investment rules must respectively be formulated in order to be consistent with the institution of social security in general.

Within a framework of reform towards privatization, emphasis on a minimum pension amount may help the reform discussion and the respective transition be more successful. Urging people to participate in funded schemes instead of making the latter mandatory has also proved to have some positive reactions. (Orenstein 2013). Finally, it is always important to allow time for public debate and gradual implementation. In the case of Sweden, even though time was allowed to process the reform, this proved to be less than the one needed when looking back (Könberg et al. 2006).

The expected capital available coming from a potential funded scheme in Greece, under the aforementioned assumptions and conditions can be found below. Table 11 below shows annual amounts at indicative intervals per decade for contributions, benefits and reserves. The reserves are calculated as the reserve of the previous year increased by $3 \%$ (an estimated return rate for assets) plus the annual surplus of contributions minus benefits for the current year.

Table 11. Funded scheme fiscal evolution (current prices, in mil.euros).

\begin{tabular}{cccc}
\hline Year & Contributions & Benefits & Reserve \\
\hline 2017 & 3751 & 1 & 3750 \\
2020 & 3752 & 14 & 15,543 \\
2030 & 4766 & 200 & 68,670 \\
2040 & 6585 & 1410 & 149,214 \\
2050 & 8911 & 5025 & 255,722 \\
2060 & 12,120 & 11,131 & 371,500 \\
\hline
\end{tabular}

Source: calculations by authors.

The total reserve for 2060 is almost 372 billion euros, estimated with a 3\% return rate for assets. To appreciate the magnitudes involved, we note that the Greek National Debt in 2016 was 312 billion euros and the GDP for 2060 was projected (EPC 2015a) to be 725 billion euros in current prices-meaning that reserves amount to $51 \%$ of GDP. If this amount corresponds to net savings, the availability of these funds could prove a major impetus to growth. Recall that private sector savings have been negative in Greece since before the crisis (Meghir et al. 2017). A new funded pension scheme of this magnitude would have a non-negligible effect on the availability of investment funds for the Greek economy, with a positive effect on growth. The transition to a new capitalized supplementary insurance system aims both at better return on policyholders' contributions with a view to improving the level of retirement benefits compared to the existing system as well as boosting the Greek economy through investments. Since Greece is part of the European Commission, the rules and regulations of the latter must be respected, however an adaptation that will help invest a large portion of the accrued capital locally thus improving the internal market and the Greek economy is deemed legitimate (MoL 2019).

Furthermore, the total debt of the state could be significantly reduced because of two different reasons. To begin with, the total implicit ${ }^{11}$ debt of the Greek pension system, as calculated with the open method approach, is one of the larger in Europe, based on the 2015 data, showing a slightly better trend based on 2018 data (DG ECFIN 2020). As the fiscal burden from the public pensions will partially be alleviated from the introduction

11 Implicit (also mentioned as unfunded) pension liabilities measure governments' long-term commitments to current and future generations of pensioners. 
of the funded scheme, this will help the long-term implicit pension liabilities. To go on, the capital accrued from the funded scheme will help promote national investments and long-sought growth, to boost economy. The general government debt of the Greek state amounted to 166\% GDP for the year 2019 (Eurostat 2020), which further proves the need for reforms in the direction of growth and a smaller state pension pillar.

The numbers mentioned in the table above are also depicted in Figure 3 below:

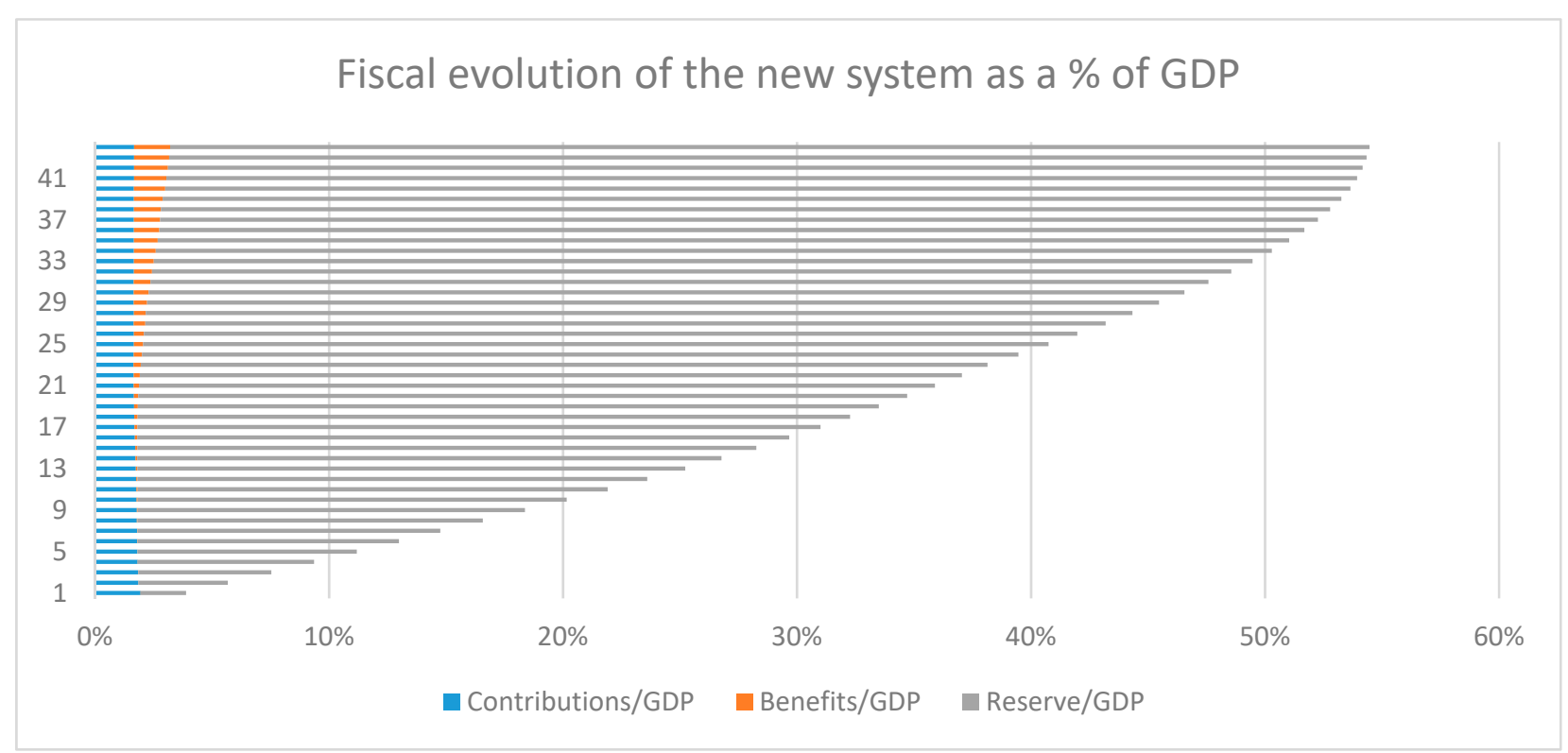

Figure 3. Contributions and benefits for the total population for the new defined contribution fund, reserve of the new defined contribution fund with $3 \%$ annual return rate. (Source: Calculations by authors).

\section{Conclusions}

Mandatory funded components in pension systems may promote savings for the economy and investments, and might alter the macroeconomic links between pensions and the economy, while simultaneously contributing to the solution of fiscal dilemmas. They do so by generating income for pensioners and alleviating the general government budget from a part of the implicit pension debt in the long term. In the short term, if the case in point includes a transition, which is frequently the case, the issue of accrued rights has to be carefully looked into before the reform.

As, however, funded schemes make contributors more subject to the risks of fluctuations in stock and bond markets, it is very important to anticipate possible rates of return and identify investment strategies to achieve them, especially in an era where quantitative easing has reduced returns greatly. In the long term, different combinations of contribution rates, rates of return and annuity values, indicate that it is possible to achieve a decent replacement rate from the funded component, which can contribute to increasing the total replacement and income for old age. Such a component can make a valuable contribution to overall system adequacy.

In Greece, the interest in a new system is two-fold. First, the present overall pension system is in constant need of state subsidies by approximately $50 \%$ yearly (Government Official Journal 2018). Secondly, there is increasing awareness of the policy makers that failure to reform the system conclusively can generate fiscal burdens on the state which in turn may lead to pension reductions or increased contributions. The latter may also lead to a vicious circle of unemployment, disinvestment and economic recession and ultimately to the extended need for financial assistance as in the case of Greece (European Commission 2020). A funded component, supplemented with a safety net and other pillars of a multi-pillar pension system, may serve as an important societal tool in order to cater 
for the financial pressure from ageing and enhance post-retirement stability, supporting the financing of consumption after retirement. At the same time, it may help reduce implicit pension debt and general government in a direct and indirect way respectively, by reducing future pension deficits and boosting economy and growth, which will consequently help increase employment. Finally, amassing contributions from the new funded scheme corresponding to large percentages of GDP and investing them could lead to safer pensions and better returns. If used wisely and well organized, political alternation has minimum impact.

Author Contributions: All authors have contributed substantially to this work. Conceptualization, G.S. and P.X.; Methodology, G.S.; Software, G.S.; Validation, G.S.; Formal Analysis, G.S.; Investigation, G.S.; Resources, G.S., P.T. and P.X.; Data Curation, G.S.; Writing-Original Draft Preparation, G.S.; Writing-Review \& Editing, G.S., P.T. and P.X.; Visualization, G.S. Supervision, G.S., P.T. and P.X.; Project Administration, G.S., P.T. and P.X.; Funding Acquisition, P.X. All authors have read and agreed to the published version of the manuscript.

Funding: The publication of this paper has been partly supported by the University of Piraeus Research Center. More specifically, the APC was funded by the University of Piraeus Research Center.

Acknowledgments: The authors thank the referees for their comments which helped to improve the manuscript. The authors would also like to thank Vasiliki Takou and Alberto La Mantia for useful insight regarding the best way to present data for replacement.

Conflicts of Interest: The authors declare no conflict of interest.

\section{References}

Barr, Nicholas. 2000. Reforming Pensions: Myths, Truths, and Policy Choices (Working Paper). Washington, DC: International Monetary Fund.

Bielawska, Kamila, Agnieszka Chłon-Domińczak, and Dariusz Stańko. 2017. Retreat from Mandatory Pension Funds in Countries of the Eastern and Central Europe in Result of Financial and Fiscal Crisis: Causes, Effects and Recommendations for Fiscal Rules. Warsaw: Instytut Zarządzania Ryzykiem Społecznym.

Bijlsma, Michiel, Casper van Ewijk, and Ferry Haaijen. 2014. Economic Growth and Funded Pension Systems, Netspar Discussion Papers. Netspar Discussion Paper No. 07/2014-030. Available online: https:/ /ssrn.com/abstract=2470544 (accessed on 30 October 2020). [CrossRef]

Carone, Giuseppe, and Aino Salomäki. 2001. Reforms in Tax-Benefit Systems in Order to Increase Employment Incentives in the EU. European Commission. Economic Paper Number 160. September. Available online: http://europa.eu.int/comm/economy_ finance (accessed on 30 October 2020).

Cavallini, Pietro, Carmeci Gaetano, and Millo Giovanni. 2013. Are Funding of Pensions and Economic Growth Directly Linked? New Empirical Results for Some OECD Countries. Trieste: EUT Edizioni Università di Trieste.

Davis, Philip E., and Yuwei Hu. 2008. Does Funding of Pensions Stimulate Economic Growth? Journal of Pension Economics and Finance 7: 221-49. [CrossRef]

DG ECFIN. 2020. Quarterly Report on the Euro Area Volume 19, No 2. Institutional Paper 135. October 2020. Luxembourg: Publications Office of the European Union.

Economic Policy Committee (EPC). 2015a. The 2015 Aging Report-Underlying Assumptions and Projection Methodologies. Luxembourg: Publications Office of the European Union.

Economic Policy Committee (EPC). 2015b. Greek Country System Fiche 2015. Athens: Hellenic Actuarial Authority.

Economic Policy Committee (EPC). 2015c. The 2015 Aging Report: Economic and Budgetary Projections for the EU Member States (2013-2060). Luxembourg: Publications Office of the European Union.

Economic Policy Committee (EPC). 2018. The 2018 Aging Report: Economic and Budgetary Projections for the EU Member States (2016-2070). Luxembourg: Publications Office of the European Union.

Economic Policy Committee (EPC). 2020. The 2021 Aging Report: Underlying Assumptions and Projection Methodologies. Institutional Paper 142. November 2020. Luxembourg: Publications Office of the European Union.

European Commission. 2007. Pensions Schemes and Projection Models in EU-25 Member States. Luxembourg: Office for Official Publications of the European Communities.

European Commission. 2008. Privately Managed Funded Pension Provision and Their Contribution to Adequate and Sustainable Pensions. Luxembourg: Publications Office of the European Union.

European Commission. 2010. Green Paper towards Adequate, Sustainable and Safe European Pension Systems. Luxembourg: Publications Office of the European Union. 
European Commission. 2012. WHITE PAPER. An Agenda for Adequate, Safe and Sustainable Pensions. Luxembourg: Publications Office of the European Union.

European Commission. 2018. European Commission Pension Adequacy Report 2018 Volume 1. Luxembourg: Publications Office of the European Union.

European Commission. 2020. Financial Assistance to Greece. Available online: https:/ / ec.europa.eu/info/business-economy-euro/ economic-and-fiscal-policy-coordination/eu-financial-assistance/which-eu-countries-have-received-assistance/financialassistance-greece_en\# (accessed on 30 January 2020).

Eurostat. 2012. Euro Yield Curves-Annual Data (Last Update 2/3/2012). Available online: https: / appsso.eurostat.ec.europa.eu/ nui/show.do?dataset=irt_euryld_a\&lang=en (accessed on 5 July 2012).

Eurostat. 2015. Population Projections 2013. Available online: http:/ / ec.europa.eu/eurostat/statistics-explained/index.php/People_ in_the_EU_\%E2\%80\%93_population_projections\#Europop2013_.E2.80.94_population_projections4 (accessed on 14 January 2017).

Eurostat. 2018. Euro Yield Curves-Annual Data (Last Update 4/7/2018). Available online: https: / appsso.eurostat.ec.europa.eu/ nui/show.do?dataset=irt_euryld_a\&lang=en (accessed on 18 July 2018).

Eurostat. 2019. Expenditure on Pensions. Available online: https://ec.europa.eu/eurostat/statistics-explained/index.php/Social_ protection_statistics_-_pension_expenditure_and_pension_beneficiaries (accessed on 27 January 2019).

Eurostat. 2020. General Government Gross Debt 2019. TEINA225. Available online: http:/ / appsso.eurostat.ec.europa.eu/nui/show. do?dataset=teina225\&lang=en (accessed on 28 November 2020).

Feldstein, Martin. 1995. Fiscal policies, capital formation, and capitalism. European Economic Review 39: 399-420. [CrossRef]

Feldstein, Martin. 1996. How Big Should Government be? (No. w5868). Washington, DC: National Bureau of Economic Research.

Feldstein, Martin. 1998. Privatizing Social Security. Chicago: University of Chicago Press.

Góra, Marek, and Edward Palmer. 2004. Shifting Perspectives in Pensions. Discussion Paper No. 1369. Bonn: Institute for the Study of Labor (IZA).

Góra, Marek, and Edward Palmer. 2020. NDC: The Generic Old Age Pension Scheme. In Progress and Challenges of Nonfinancial Defined Contribution Pension Schemes: Addressing Marginalization, Polarization, and the Labor Market. Edited by Robert Holzmann, Edward Palmer, Robert Palacios and Stefano Sacchi. Washington, DC: The World Bank, pp. 167-88.

Government Official Journal. 2018. Law 4549: Issue 105. Athens, Greece, June 14. Available online: www.et.gr (accessed on 30 October 2020).

Gratton, Lynda, and Andrew Scott. 2018. The 100-Year Life. London: Bloomsbury.

Hellenic Association of Insurance Companies. 2020. Annual Reports. Available online: http:/ / www1.eaee.gr/etisia-ekthesi (accessed on 30 March 2000). (In Greek).

Holzmann, Robert, and Richard Hinz. 2005. Old Age Income Support in the 21st Century: An International Perspective on Pension Systems and Reform. Washington, DC: The World Bank.

International Monetary Fund (IMF). 2017. Negative Interest Rate Policies_Initial Experiences and Assessments. Washington, DC: IMF.

Iyer, Subramaniam. 1999. Actuarial Mathematics of Social Security Pensions. Geneva: ILO and ISSA.

Könberg, Bo, Edward Palmer, and Annika Sundén. 2006. The NDC Reform in Sweden: The 1994 Legislation to the Present. In Pension Reform: Issues and Prospects for Non-Financial Defined Contribution (NDC) Scheme. Edited by Robert Holzmann and Edward Palmer. Washington, DC: The World Bank, pp. 449-66.

Lindbeck, Assar, and Mats Persson. 2003. The Gains from Pension Reform. The Journal of Economic Literature 41: 74-112. [CrossRef]

Lukaszl, Rachel, and Lawrence H. Summers. 2019. On Secular Stagnation in the Industrialized World. In Brookings Papers on Economic Activity. Washington, DC: Brookings Institution Press.

Meghir, Costas, Christopher A. Pissarides, Dimitri Vayanos, and Nikolaos Vettas. 2017. Beyond Austerity: Reforming the Greek Economy. Edited by Costas Meghir, Christopher A. Pissarides, Dimitri Vayanos and Nikolaos Vettas. London and Cambridge: The MIT Press.

Ministry of Labour (MoL). 2019. Working Group on the Proposals for the Restructuring of Auxiliary Insurance in Greece. Findings and Conclusions. Athens: MoL.

OECD. 2019a. Pension markets in Focus. Paris: OECD Publishing.

OECD. 2019b. Pensions at a Glance 2019. OECD and G20 Indicators. Paris: OECD Publishing.

OECD. 2011. Taxation and Employment. OECD Tax Policy Studies No 21. Paris: OECD Publishing.

OECD. 2013. Pension Markets in Focus. Paris: OECD Publishing.

OECD. 2015. Pensions at a Glance 2015. OECD and G20 Indicators. Paris: OECD Publishing.

OECD. 2017. Pensions at a Glance 2017. OECD and G20 Indicators. Paris: OECD Publishing.

OECD. 2020. Pensions Funds in Figures. June 2020. Paris: OECD Publishing.

OECD.stat. 2020. Available online: https:/ / stats.oecd.org/index.aspx?queryid=594 (accessed on 30 March 2020).

Orenstein, Mitchell A. 2013. Pension Privatization: Evolution of a Paradigm. Governance 26: 259-81. [CrossRef]

Paparigopoulos, Pechlivanides. 2019. Social Insurance Law, 3rd ed. Athens: Nomiki Vivliothiki.

Plamondon, Pierre, Anne Drouin, Gylles Binet, Michael Cichon, Warren McGillivray, Michel Bédard, and Hernando Pérez-Montas. 2002. Actuarial Practice in Social Security. Geneva: ILO and ISSA.

Rajan, Amin. 2019. Quantitative Easing: The End of the Road for Pension Investors? Kent: Amundi-CREATE-Research. 
Schmelzing, Paul. 2020. Eight Centuries of Global Real Interest Rates, R-G, and the 'Suprasecular' Decline, 1311-2018, Staff Working Paper No. 845. London: Bank of England.

Symeonidis, Georgios, and Georgia Venetsanakou. 2016. Pensions Resuscitation. Conference Paper. The Hague: WorldPensionSummit. Symeonidis, Georgios. 2016. World Bank Social Protection and Labor Discussion Paper: The Greek Pension Reform Strategy $2010-2016$. Washington, DC: World Bank.

TARKI. 2008. PENMICRO: Monitoring Pension Developments through Micro Socioeconomic Instruments Based on Individual Data Sources: Feasibility Study. Final Report for The European Commission Employment, Social Affairs and Equal Opportunities DG EMPL E4 Unit. Bruxelles: European Union.

Van Rijckeghem, Caroline. 1997. Social Security Tax Reform and Unemployment: A General Equilibrium Analysis for France. IMF Working Paper. Washington, DC: International Monetary Fund.

Zandberg, Eelco, and Laura Spierdijk. 2013. Funding of pensions and economic growth: Are they really related? Journal of Pension Economics and Finance 12: 151-67. [CrossRef] 